Оригинални научни рад

УДК 373.22:59 811.163.41

373.22:59^811.161.1

Примљен: 31. март 2021.

Прихваћен: 13. април 2021.

Јелена Б. Лепојевић ${ }^{1}$

https://doi.org/10.46630/phm.13.2021.41

Универзитет у Нишу

Филозофски факултет

Департман за руски језик и књижевност

\title{
ЗООНИМИ У ФУНКЦИЈИ ИНВЕКТИВЕ: ДА ЛИ ЈЕ ЧОВЕК ЧОВЕКУ САМО ВУК?
}

Секундарне семантичке реализације именица чија је примарна функција да именују животиње могу се односити како на предмете тако и на лица. Продуктивност секундарних значења која реферишу на лице веома је висока, понајвише када се њима указује на негативне карактеристике.

Овај рад се првенствено бави анализом и класификацијом инвективних секундарних значења забележених под одредницама за зоониме у руским и српским речницима. Резултати истраживања формирани су на основу поређења како секундарних значења тако и самих зоонима код којих су се таква значења развила у руском, односно српском језику. Поред лексичко-семантичких карактеристика, водећи се принципима компаративне анализе, у раду ћемо се осврнути и на творбени аспект, као и на особености развоја вишезначности. У току истраживања примењиване су традиционалне лингвистичке методе: метода узорковања, лексичко-семантичка, компаративна, дескриптивна метода, квантитативна анализа и, када је грађа то захтевала, анализа речничких дефиниција.

Кључне речи: зооним, инвектива, семантичка деривација, полисемија, секундарно значење, руски језик, српски језик

\section{1. Уводна разматрања}

Човекова веза са животињама стара је колико и само човечанство. Животиње су присутне у животу људи као радна снага, извор хране и одеће, као друштво и као заштита. Од најранијих људских заједница животиње су укључене у све сегменте људског постојања. Отуда је сасвим природно да је човек, посматрајући понашање животиња које су му блиске, увидео одређене сличности са људским понашањем.

Веза која је успостављена на релацији човек - животиња у сво-

1 jelena.lepojevic@filfak.ni.ac.rs 
јој основи је двосмерна: најпре је човек животињама приписивао људске особине (тако је пас веран, лисица лукава, свиға прљава, и томе слично), а затим је смер поређења преокренут, па су се новим метафоричким преношењем људи код којих су уочене одређене особине називали именима животиња.

У основи, свако именовање човека називима животиња представља номинациону јединицу позитивне, или чешће, негативне експресије. Експресивна значења, за која С. Ристић каже да се реализују на плану језичког система као одређени национални и културни стереотипи (2004: 242), евидентно леже у основи секундарних реализација зоонима. Животиње у таквим стереотипима, у језичкој слици света уопште, имају значајну и активну улогу.

Најпре, сматра се да се зооними, под којима подразумевамо све речи чија је основна функција да номинују неку животињу, као и речи произведене на њиховим основама, срећу у свим светским језицима. Ради се о лексичким групама формираним у најранијим фазама развоја лексикона, те су стога многи називи животиња међу језицима, посебно оним сродним, исти или слични.

Такође, у свим светским језицима постоји симболика повезана са зоонимима. Она се није развијала подједнако већ је зависила од улоге коју је одређена животиња имала у неком друштву. За одређене животиње развила се иста симболика у већини култура: лисица је симбол лукавства код многих народа, мајмун симболизује подражавање и томе слично. С друге стране, за сваки народ постоје и специфични механизми за преосмишљавање иницијалног у секундарно значење. Како истиче Маслова,

„русское слово свинья является символом а) грязи, б) неблагодарности, в) невоспитанности; для англичан pig означает обжору; для киргизов, казахов, узбеков и других мусульманских народов сюда добавляется коннотация чисто религиозного плана, в результате чего чочко (свинья) становится резко бранным словом; во вьетнамской же картине мира свинья - символ глупости" (2004: 54).

Језичка слика света о којој говори Маслова формира тип човековог односа према свему што га окружује: природи, животињама, чак и себи као елементу света (2004: 62-65). За Р. Драгићевић, језичка слика света је израз човекове способности да моделује и структурира слику стварности у одређеној лингвокултуролошкој заједници (2010: 12) и као таква, специфична је само за дату заједницу.

Зоонимска метафорика истраживана је са различитих аспеката, многи аутори су кроз своја истраживања покушали да представе симболику животиња у језичкој слици света. Како се углавном ради о ауторима 
са несловенског говорног подручја (Хајнс 1999; Мишар 2002; Бајдер-Ђезуато 2003; Кјелтика 2005 - према RANĐELOVIĆ 2012: 91), а матерњи језик као носилац културе обликује језичку слику света, у тим истраживањима постоје општа места, симболика присутна код више језика, али постоје, с друге стране, и они аспекти који ван граница језика истраживања нису применљиви. Стога је потреба за једним оваквим истраживањем очигледна.

На српском говорном подручју метафорична значења зоонима проучавали су А. Ранђеловић (2012), Н. Ристивојевић Рајковић (2008, 2014) и С. Новокмет (2012), с тим да ниједно од тих истраживања нема компаративни карактер.

И поред богатих истраживања на овом пољу, новина овога рада огледа се у приступу и организацији грађе: у наш корпус ушле су само секундарне семантичке реализације зоонима које се употребљавају у инвективној функцији, у значењу грдње, прекора, увреде (инвектива од лат. invectivus). Овако организовано истраживање нема за циљ да пропагира употребу увредљивих речи нити да на било који начин промовише омаловажавање других. Ради се о једном лингвистичком проблему који је представљен кроз материјал увредљиве садржине а који је, судећи према речничким дефиницијама и живој језичкој пракси, дубоко укорењен како у српској тако и у руској лингвокултуролошкој средини. Стога сматрамо да лексеме из представљеног семантичког спектра треба познавати не зарад вређања других, већ зашто што непознавање њихових значења може довести до бројних неспоразума у комуникацији.

\section{2. Творбени аспект - семантичка деривација и вишезначност}

Поред настанка нових речи различитим творбеним процесима и позајмљивања из других језика, полисемија представља један од изузетно активних механизама за богаћење лексичког фонда једног језика и проширивање значењских структура постојећих речи.

Вишезначне речи резултат су процеса који називамо семантичком деривацијом. Сам термин семантичка деривација, као и њен статус, тумачи се двојако: једна група аутора, међу којима су руски лингвисти В.В. Виноградов, Л.В. Шчерба (Щерба), А.А. Потебња (Потебня), као и Р. Маројевић ${ }^{2}$, овај процес доживљава као чисто творбени, и сматрају да речи настале на овај начин имају карактеристике хомонима. Другачијег су мишљења лингвисти попут Ј.Д. Апресјана (Апресян), С.Н. Денисенко, чије ставове на српском говорном подручју деле и Р. Драгићевић ${ }^{3}$ и J. Ма-

2 Више у: MAROJEVIĆ 2005.

3 Више о процесу семантичке деривације у: DRAGIĆEVIĆ 2018. 
тијашевић ${ }^{4}$, који у овом процесу виде могућност развијања вишезначности код лексема.

Став прве групе лингвиста поприлично је ревидиран у савременим језичким истраживањима, јер се семантички деривати (термин према ASADČAJA 2015: 53) не могу поистоветити са хомонимима, који се дефинишу као речи које имају истоветну форму, али у чијем значењу не постоји ништа заједничко (APRESJAN 1995: 183).

Заправо, семантичка деривација није вид деривације, како то њен назив сугерише, већ се ради о процесу развијања секундарних значења. Статус овог процеса не може се дефинисати као чисто дериватолошки, с обзиром на то да не постоје морфеме које носе функцију творбених форманата, нити је чисто лексички. Могло би се рећи да он представља додирну тачку два поменута језичка нивоа.

\section{3. Лексичко-семантички аспект}

Човекова стална потреба да именује предмете и појаве којима је окружен, као и ограничени лингвистички ресурси у језику, довели су до тога да је већина речи у језику вишезначна. Употребом постојећих речи у новим контекстима развијају се нова значења (више у BELOŠAPKOVA 1999, 197-236).

Полисемија или вишезначност описује се као способност лексеме да има више семантичких реализација (ROZENTALJ, GOLUB i dr. 2010: 24). Вишезначност је својствена свим речима сем терминима, који по замисли не смеју носити више од једног значења.

Код вишезначних речи разликујемо примарно и секундарно, односно секундарна значења. Као основно значење лексеме означава се оно код кога имамо „директан номинациони однос између лексичке јединице и онога што је њоме означено" (GORTAN PREMK 2014: 132). Основно значење представља прототип према коме се, семантичком деривацијом, развијају секундарна значења. Те секундарне семантичке реализације не морају увек бити блиске основном значењу, али су њиме мотивисане и међу њима се увек уочава семантичка веза. Као што закључује Р. Драгићевић, сличност изворног и циљног појма никад није апсолутна и комплетна, већ је заснована на некој компоненти, као што су функција, облик, боја и томе слично (2010: 148).

Као основне механизме остваривања полисемије унутар лексеме, Д. Гортан Премк наводи лексичке индукторе - метафору, метонимију и синегдоху (2004: 115). Међу лексичким метафорама она издваја и метафоричне асоцијације засноване на семама колективне експресије (2004: 107-108), под којима се подразумевају „семантичке компоненте заснова4 Исто: MATIJAŠEVIĆ 2019, 122-145. 
не на уверењима и представама целе језичке заједнице” (DRAGIĆEVIĆ 2010: 72). На колективну експресију, истиче Р. Драгићевић, највише утичу култура, традиција и обичаји једног народа (2010: 73).

Како ћемо у наставку и видети, секундарне семантичке реализације зоонима заиста су засноване на уверењима и представама које деле чланови одређене језичке заједнице. Ради се о важној компоненти националног менталитета у којој се огледа однос једне заједнице како према животињама, тако и према другим члановима те заједнице. Поменути однос у руској и српској лингвокултуролошкој заједници, разматраћемо на материјалу зоонима код којих су се развила секундарна значења која негативно реферишу на човека. Указаћемо и на природу везе која се са човеком успоставља.

\section{4. Секундарне семантичке реализације зоонима}

Код зоонима, речи чијим се примарним значењем именује нека животиња, уочава се висока продуктивност семантичке деривације. Зооними, као тип именица, веома су погодни за развој секундарних значења. Секундарне семантичке реализације зоонима употребљавају се да означе лица и предмете. Секундарна значења која реферишу на лица су много продуктивнија категорија од оних којима се означавају материјалне реалије.

Зооними у пренесеном значењу, када реферишу на човека, могу да се употребе да означе физички изглед (како пожељне - видра, ждребии, змај, вучииа, тако и непожељне физичке особине - акреп, бумбар, медвед/мечка, прасац/прасица, слон/слоница), интелектуалне способности (овиа, ћурка, гуска, волина, говедо, мајмун), карактерне особине (аждаја, амеба, вашка, гњида, змија, лешинар, мазга), свеопште понашање (камелеон, крпел, папагај, паун), емотивна стања (кукумавка, осица, рис, тигрии, $а)$.

Интересанто запажање даје Г. Штасни да „и немаркирана лексема животиюа са општим значењем има у секундарној семантичкој реализацији значење чији је денотат човек” (ŠTASNI 2013, 84) и указује на семантичке вредности и природу секундарних реализација ове именице (2013: 85).

Вреди напоменути да се код значајног броја зоонима развило више секундарних значења на основу којих се могу уврстити у две или више група, које смо на основу прикупљених примера и формирали.

Наш рад биће усмерен искључиво на употребу руских и српских зоонима ексцерпираних из речничке грађе који се користе у функцији увреде, у негативној конотацији, док смо примере из позитивног семантичког спектра методолошки занемарили. Они представљају тему засеб- 
ног истраживања.

\section{1.Зооними који реферишу на физичке карактеристике}

Зооними чија секундарна значења реферишу на човеков физички изглед, веома су бројна група у оба испитивана језика. Ово је веома продуктиван начин метафоризације зоонима. На основу речничких дефиниција, уочавају се три подгрупе оваквих значења: прва се односи само на мушкарце, друга искључиво на жене, а постоји и трећа група са квалификатором човек или особа, која се, формалнограматички, може односити на оба али се ипак више користи за припаднике мушког пола.

Метафорички пренос физичких особина заснива се на сличности у изгледу, таква секундарна значења налазимо код именица мајмун (RSJ 2007) у српском и обезъяна (SE) у руском, који се семантизују на исти начин: ружан човек.

У оба језика су се подједнако развила секундарна значења именице слон (RMS; SE) - дебео, неспретан човек.

Затим на физички изглед реферишу и називи птица: у српском канаринаи, (RSŽ), у руском попугай (SE), означавајући упадљиво, а неукусно обученог мушкарца.

Код именица медвед (RSANU) и медведь (SE) долази до незнатног мимоилажења секундарних значења: док поклапање постоји у сегменту „крупан, али незграпан и неотесан човек”, у речнику српског језика забележено је и значење „ограничен, глуп човек ”.

Мали, неугледан, неприметан човек означава се различитим зоонимима: у српском језику то значење се развило код именице жабаи, (RSANU), док се у руском, у истом значењу, употребљава именица букашка (SE). Примарним значењем ове руске именице номинују се различите врсте инсеката, њено секундарно значење поједнако је применљиво на оба пола, док се српска именица употребљава претежно за мушки род.

У српском језику секундарна значења која реферишу на лице мушког пола развила су се и код следећих зоонима: јараи - човек који брадом личи на јарца, ружан, неугледан човек (RSANU), певчић - недозрео, недорастао младић; размажен, кочоперан младић (RSANU).

С друге стране, када се на руском говорном подручју говори о крупном, дебелом, незграпном човеку, то значење може се пренети зоонимима гиббон (TSRS), бегемот (нилски коњ), боров (брав) или тюлень, у значењу фока (BTSK).

Када о истим физичким особинама говоримо код жена, користе се зооними попут слоница (RSJ 2007) и слониха (SE), крава (RSANU) и корова (SE).

На негативну конотацију крупне женске грађе указују и секун- 
дарна значења зоонима ајкула (RSŽ) и мечка (RSANU) на српском говорном подручју, док се на руском за жену која грађом подсећа на мушкарца користи именица бабуин (павијан).

Интересантна је чињеница да се разматрано секундарно значење развило код две руске именице сличног семантичког спектра - лошадь (коњ) и кобыла (SE). Оба руска зоонима су именице женског рода, што није случај са српском именицом коњ, и употребљавају се за особе женског пола. У српском језику су у употреби именице кобила и кобилетина (RMS), за које се у речнику каже да се користе погрдно за женску особу, али се њима превасходно карактерише нечије понашање, а секундарно изглед.

Једно од секундарних значења именица вучица, гуштер и пас (RSŽ), као и квочка и мајмуница (РСАНУ) у српском, односно жаба (TSRS) у руском језику јесте „ружна женска особа”.

Инвективна значења уочавају се и код именица глиста (RSŽ) и выдра (BTSK), које се односе на веома мршаве и стога непривлачне жене.

Следећа два зоонима налазе се на граници управо разматраних и оних којима се реферише на нечију чистоћу, односно, напоредо се користе у оба негативна контекста: крава и дропља (RSANU) означавају и гломазну и незграпну женску особу, као и лењу и неуредну жену.

Управо на чистоћу се односе и секундарна значења зоонима прасаи, крмак (RSANU) и поросёнок(SE), који се семантизују као „прљав и неуредан човек"; именице прасииа и крмача (RSANU) реферишу на прљаву женску особу, док се зоонимом свиња (RSŽ) и њеним руским парњаком свинъя (SE) могу означити оба пола. Интересантно је да се код оба народа колективна експресија развила на исти начин када је наведена животиња у питању.

Из руског језика бисмо издвојили још два зоонима: каракатица (морска сипа) указује на неспретну кратконогу особу (SE), док се секундарним значењем именице цзапля (чапља) означава веома висока, дугонога особа (SE).

\section{2. Зооними који реферишу на интелектуални капацитет}

Код великог броја српских зоонима развила су се секундарна значења која негативно реферишу на нечије интелектуалне способности. Мање-више иста објашњења могу се наћи у речницима уз следеће именице: бик (RSŽ); брав, теле, сом, колоквијално још и сомина (RMS), волоюа (RSJ 2007); буцов, во, волина, говедо, говече, гусан, јунаи, јуне, кою (RSANU) - глуп и ограничен човек.

Увредљив садржај нечијих интелектуалних способности, како бележе речници, налази се у секундарном значењу зоонима магараи 
(RSANU), као и у његовом руском лексичко-семантичком парњаку - осёл (SE). Код руског зоонима ищак (BTSK), који у себи садржани и компоненту тврдоглавости, такође се уочава ово секундарно значење. Иста семантика крије се и у секундарном значењу српског зоонима ован (RSANU), односно руских баран (SE) и верблюд (TSRS). У руском језику се именица женског рода из исте лексичке групе, овца (SE), употребљава за оба пола. Истоветна српска именица овца (RSANU), као и именица коза (RMS), такође реферишу на оба пола.

Језичка пракса показује да се у истом значењу употребљавају и српски зооними ћуран и ћурка (RMS), док њихов руски парњак, именица индюк (SE), поред значења „глуп човек”, садржи још једну компоненту значења - „надмен човек”.

Широк је дијапазон српских именица код којих секундарним значењима негативно реферишемо на интелектуалне способности припадница женског пола: крава, гуска (RSANU); гушчииа, кокошка (RMS). У истом пренесеном значењу употребљавају се именице магарица (RSŽ) у српском, односно ослица (BTSK) у руском језику.

Међу разматраним примерима уочава се разлика у зоонимима који су развили секундарна семантичка значења којима се указује на глупост: док код припадника мушког пола доминирају крупне домаће животиње, жене се углавном поистовећују са живином. Стога не можемо да се не сложимо са Н. Ристивојевић Рајковић, која каже „uočavamo da je kod žena glupost povezana pre svega sa brbljivošću (asocijacija na glasanje živine), dok je kod muškaraca vezana za izvesnu tromost i sporost” (2008: 50).

\section{3. Зооними који реферишу на понашање и карактерне особине}

Код секундарних значења зоонима са негативном референцијом на човекову личност, није увек било једноставно повући недвосмислену границу између оних којима се означава нечије понашање и оних којима се указује на карактерне црте. Често су у речничким дефиницијама ти појмови удружени, односно могу се употребити двојако. Стога примере ових група наводимо у оквиру исте класификационе целине.

Људска особина лукавости и препредености још је у најстаријим баснама приписивана лисици, а затим се људска бића са таквим особинама називају поменутим зоонимом: лисица и лисаи (RSANU) у српском, док су у руском језику то облици лиса и лисица (SE). Обема руским именицама могу се означити лица оба пола; исто важи и за српску именицу лисица, док лисаи означава мушкарца. Исто секундарно значење уочава се и код српске именице мачор (RSANU), као и код руских зоонима гусь и жук (SE).

Још једна негативна људска особина садржана у секундарном 
значењу једног зоонима јесте тврдоглавост. Речници бележе да се у таквом контексту употребљавају именице мазгов (RMS) и мазга (RSŽ), као и њихов лексичко-семантички еквивалент, руски зооним ищак (BTSK). У руском језику су, у истом значењу, у употреби и именице бычок и козёл (SE).

Лексичка грађа указује на то да се ништаван човек, вредан презира, у оба језика означава називима веома ситних животиња: ваш (RSANU) и гюида (RMS), односно вошь (BTSK) и гнида (SE), затим блоха (BTSK) и червь (SE) у руском, а гриға (RSANU) у српском језику.

Различите именице којима се номинује пас, развиле су секундарна значења којима се означава лош, суров и свиреп човек: кер, пас (RSANU); као и иукаи, (RMS) на српском говорном подручју, односно собака (SE) на руском. Поменутом руском именицом могу се окарактерисати како жене тако и мушкарци, док српске именице углавном реферишу на мушки род. Свирепост и окрутност главне су особине којима је мотивисано секундарно значење зоонима вук (RSANU).

На лошу и неморалну особу указује се и зоонимом пацов (RSANU), док секундарно значење његовог руског парњака садржи у себи нижу негативну референцију, именицом крыса (CE) означава се особа која у нама изазива осећај нетрпељивости.

Раздражљивост и склоност ка свађама садржана је у секундарном значењу именица петао (RMS), односно руске петух (SE).

Зооними којима се номинују грабљивице били су погодна база за настанак секундарних значења којима ће се особине грабљивости и безобзирности означавати код људи: у српском језику се у датом контексту користи име птице кобаи (RSANU), док је у руском језику у питању копнена животиња шакал (SE). Истоветна семантика уочава се и код животиња које су по својој физиономији и природи сличне шакалу, то су хијена (RMS), односно гиена (SE) у руском језику.

Још једна особина која се сматра негативном је некултура. Некултурна особа се, судећи према речничкој грађи, доживљава као проста, неваспитана, чак и глупа. Таква семантика садржана је у секундарним значењима зоонима стока (RMS) у српском језику, као и у два руска зоонима: медведь и свинья (SE). Потоњом руском именицом могу се окарактерисати припадници оба пола.

Једно од секундарних значења именице мазгов (RSANU) је нерадан и лењ човек. Исте особине означавају се и зоонимима трут (RMS), односно трутень (SE) у руском - нерадан човек који живи од туђег рада. Нерад и паразитски начин живота окосница су секундарних значења зоонима пијавица (RMS) и његовог руског лексичко-семантичког еквивалента пиявка (BTSK). Речју паразит објашњава се и фигуративно значење српских именица глодар (RSANU) и стеница (RMS). 
За именицу стеница, иако се то у речницима не наводи, у језику је уобичајена употреба у значењу досадан човек, чак постоји и колоквијализам досадан као стеница. С друге стране, према речничким наводима, наведено секундарно значење уочено је код зоонима крпель и галеб (RSANU) или гусеница (RMS).

„Човек без части” је секундарно значење које се развило код српске именице крмак (RSANU) и руске поросёнок (SE). За особе женског пола у употреби је зооним крмача (RSANU). Ови зооними представљају синониме за реч свиња код које се развио широк спектар негативних секундарних значења.

Називом птице кукавица (RSANU), која полеже своја јаја у туђа гнезда, као и зоонимом миш (RSANU), животињице која се крије по рупама, означава се особа која нема довољно храбрости, која је плашљива и слаба. Овакво секундарно значење уочава се и код руске именице теленок (TSRS). Разматране карактеристике могу се наћи и у секундарном значењу зоонима амеба (RSŽ), али и знатно више од тога, јер сам избор једноћелијског организма којим се реферише на људско биће говори о његовој безличности и безначајности. Уз то, у речничкој дефиницији стоји још и беспосличар, нерадник, ленштина.

Код следеће групе зоонима до преноса значења дошло је на основу понашања запаженог код животиња. Тако се човек који некритички само понавља туђе речи назива папагајем (RSANU), док је графијски лик истоветне руске именице попугай (SE). За човека који опонаша друге, користи се зооним мајмун (RSANU), то јест у руском обезьяна (SE). На основу способности визуелног прилагођавања околини уочене код камелеона, особа која мења своје мишљење и понашање према приликама и потребама поистовећује се са овом животињом - камелеон (RSANU) у српском, односно хамелеон (SE) у руском језику. Исто тако, секундарна значења развила су се и код именица паун (RSANU), односно павлин (BTSK), и њима се реферише на разметљиву особу која много држи до свог изгледа.

Подједнако негативно се на ове особине гледа и код особа женског пола. Код значајног броја зоонима развила су се секундарна значења „зла и покварена жена”. У наведеном контексту употребљавају се зооними куја и кучка (RSANU) у српском, док се у руском употребљава синонимична именица сука (BTSK); као и бульдог, кобра, рысь (којом се може означити и лукава жена), щука (TSRS). У истом значењу употребљавају се и зооними совуљага и шкорпија (RMS), и змија (RSŽ). Овој групи припадају српске именице аждаја и аспида (RSANU), док се њиховим руским еквивалентима, именицама дракон (BTSK), односно аспид (BTSK), углавном реферише на исте особине код мушкараца. Још једна руска именица 
чије секундарно значење одговара разматраној групи јесте ехидна (SE), с тим да се она употребљава подједнако за оба пола.

Уз именицу вучища (RSANU) стоји објашњење „немилосрдна, окрутна женска особа".

Поред већ разматраних, једно од секундарних значења именице краветина (RSANU) је и лења жена.

Немирна, неспретна женска особа у оба језика означава се именицом коза (RSANU; SE).

На непожељно понашање реферише се и зоонимима кокошка (RSŽ) и мајмуница (RSANU), те се жени на коју се ове именице односе замера да је примитивна и проста.

Указујемо на једну разлику на међујезичком плану: док се на српском говорном подручју причљивост доживљава као особина присутна само код женског пола, и у језичкој је пракси да се таква жена назива крекетушом (RSANU), при чему аналогна форма за мушки род изостаje, у руском језику се таква особина приписује припадницима оба пола и у том значењу је у употреби зооним сорока (SE), у преводу на српски сврака. Исто секундарно значење уочава се и код српске именице чавка (RMS). Блиска по значењу је и именица ворона (TSRS), за коју се у речнику наводи да се односи на бучну, грлату жену.

Од руских зоонима чија секундарна значења реферишу на људске особине, а која немају кореспондирајуће форме у српском језику, навели бисмо именицу пустельга (SE), којом се реферише на лакомислену особу. Интересантно је да се код преводног еквивалента овог руског зоонима, именице ветрушка, којом се означава птица из породице соколова, у српском језику није развило секундарно значење. Овакво секундарно значење би код српске именице било веома адекватно с обзиром на то да је сам зооним мотивисан именицом ветар.

\section{4. Зооними који реферишу на сексуалност}

Међу секундарним семантичким реализацијама зоонима има и оних којима се реферише на нечију полну активност или потребу која премашује неке друштвеноприхватљиве норме. Иако се оваквим лексемама такво понашање маркира као непримерено, мушкарци се таквим именицама означавају као похотљиви - ајгир, бик (RSANU), ждребаи (RSJ 2007), односно кобель (SE) у руском, док се жена која се тако понаша обележава као жена лаког морала, неморална жена, у неким речницима чак и као блудница и проститутка. У српском језику овакво секундарно значење развило се код зоонима ајгирица, камењарка и куја (RSANU), затим вижла (RMS) или сојка (RSJ 2007). Истоветна значења развила су се код руских именица дрофа и сука (BTSK), као и код зоонима кошара, кошка, 
чайка (TSRS). Напоменимо и то да се именица куjа/кучка и њен руски парњак сука не користе само са овом конотацијом већ се њима означава и уопштен негативан однос према некој женској особи.

У оба словенска језика јављају се секундарна значења зоонима којима се реферише на превареног мушкарца. У питању су варијанте једне исте лексеме, јараи и јарчина (RSANU) у српском, односно козерог у руском. Метафоризација је у овом случају била повезана са семом изгледа, јер у оба језика постоји израз „набити некоме рогове”, у значењу преварити партнера. С тим у вези, Н. Ристивојевић Рајковић каже:

„Da je promiskuitetna žena predmet opšte društvene osude koja prevazilazi nju kao pojedinca pokazuje i leksema rogonja, odnosno hanrei (etimologija ove reči je „kastrirani pevac”) - jedan od retkih nosilaca negativne konotacije kad je reč o muškarcima i seksualnosti, samo zato što se odnosi na seksualno ponašanje partnerke" (2008: 51).

У наведену лексичко-семантичку групу могу се уврстити, према својим секундарним значењима, и следеће именице: мачкар - онај који јури за женама (RSANU), ован је други назив за љубавника (RSŽ), док руска именица тёлка (SE) указује на младу, неискусну женску особу.

\section{5. Закључна разматрања}

У свим светским језицима постоји симболика повезана са зоонимима која се није развијала подједнако већ је зависила од улоге коју је одређена животиња имала у неком друштву, као и од тога како је друштво доживљавало одређењу животињу. Та симболика повезана са животињама одражава се у њиховим секундарним семантичким реализацијама.

Секундарна значења уочена код речи чија је основна функција да номинују животињу била су основна тема нашег рада. Анализом су обухваћени примери из руског и српског језика, ексцерпирани из 4 српска и 3 руска речника (списак у одељку Извори).

Наш корпус чинила су 67 руска и 102 српска зоонима, код којих су уочене 80, односно 115 секундарних семантичких реализација. Знатно већи број примера у српском језику не указује на то да је овај процес активнији у том систему, већ је резултат високе продуктивности афикса који се везују за зоониме као творбене базе (сом - сомина, во - волина волона, гуска - гушчица, кобила - кобилетина, и томе слично), при чему смо сваку од ових речи сматрали засебном лексичком јединицом, док нам грађа на руском није понудила много примера именица субјективне оцене типа бык - бъчок.

Истраживање је показало да су се у руском и српском језику, који су како генетски тако и системски веома блиски, секундарна значе- 
ња зоонима развијала по истом моделу. Полазећи од претпоставке да је сваки матерњи језик носилац културе и кроз њега се одражава културни и национални менталитет његових говорника (Маслова 2001: 60-61), резултати нашег истраживања сведоче о високом степену сличности у менталитету између говорника руског и српског језика.

Негативна метафоричка значења доминантна су особина код зоонима који се својим секундарним значењима односе на људе. Како Р. Драгићевић примећује, у зоонимској метафорици огледају се очекивања друштвене заједнице према појединцу - он не сме бити дебео, прљав, рђав и глуп (2010: 122-123).

Уз то можемо закључити да се секундарна значења зоонима налазе у колективном сазнању једне нације те представљају њену националну слику света (DRAGIĆEVIĆ 2010: 12).

Експресивна значења која су разматрана у раду реализују се као одређени национални и културни стереотипи са којима су изворни говорници датог језика упознати. Због тога сматрамо да наше, као и слична компаративна истраживања, могу бити корисна приликом учења страних језика, имајући у виду то да непознавање спектра секундарних значења одређених лексема, у нашем случају зоонима, може резултирати великим сметњама у комуникацији. Оваква ситуација могућа је и у оквирима једног језичког система, али је вероватније да до ње дође у коминикацији на страном језиком, посебно тамо где се секундарна значења на плану два језика разликују.

Осим тога, према тврдњама Р. Драгићевић, семе колективне експресије представљају значајан материјал у спознавању језичке (наивне) слике света једне лингвокултуролошке заједнице (2010: 11-13), те сматрамо да се наш допринос огледа и у представљању перспективе две лингвокултуролошке заједнице, као и у поређењу руске и српске језичке слике света.

Такође, ово истраживање једно је од ретких које се разматраним питањем бави на компаративно-контрастивном плану руског и српског језика.

\section{Цитирана литература}

APRESJAN 1995: APRESIAN, Iurii Derenikovich. Leksicheskaia semantika, Moskva: Iazyki russkoi kul'tury: Vostochnaia literatura RAN, 1995. [orig.] АПРЕСЯН, Юрий Дереникович. Лексическая семантика, Москва: Языки русской культуры: Восточная литература РАН, 1995.

ASADČAJA 2015: OSADChAIA, Alena Vladimirovna. „Poniatie semanticheskoi derivatsii", Aktual'nye voprosy filologicheskikh nauk, Kazan': Buk, 2015. [orig.] ОСАДЧАЯ, Алена Владимировна. „Понятие семантической 
деривации”, Актуальные вопросы филологических наук, Казань: Бук, 2015.

BELOŠAPKOVA 1999: BELOSHAPKOVA (red.) Sovremennyi russkii iazyk. Moskva: Azbukovnik, 1999. [orig.] БЕЛОШАПКОВА (ред.) Современный русский язык. Москва: Азбуковник, 1999.

DRAGIĆEVIĆ 2003: DRAGIĆEVIĆ, Rajna. „Mehanizmi nastajanja sekundarnih značenja leksema”, Srpski jezik, VIII/1-2, Beograd: Filološki fakultet, 2003, 221-231. [orig.] ДРАГИЋЕВИЋ, Рајна. „Механизми настајања секундарних значења лексема”, Српски језик, VIII/1-2, Београд: Филолошки факултет, 2003, 221-231.

DRAGIĆEVIĆ 2010: DRAGIĆEVIĆ, Rajna. Leksikologija srpskog jezika, Beograd: Zavod za izdavanje udžbenika, 2010. [orig.] ДРАГИЋЕВИЋ, Рајна. Лексикологија српског језика, Београд: Завод за издавање уџбеника, 2010.

DRAGIĆEVIĆ 2018: DRAGIĆEVIĆ, Rajna. „Semantička derivacija”, Srpski jezik, ХХІІІ, Beograd: Filološki fakultet, 2018, 169-177. [orig.] ДРАГИЋЕВИЋ, Рајна. „Семантичка деривација”, Српски језик, XXIII, Београд: Филолошки факултет, 2018, 169-177.

GORTAN PREMK 2004: GORTAN PREMK, Darinka. Polisemija i organizacija leksičkog sistema u srpskom jeziku, Zavod za udžbenike i nastavna sredstva, Beograd, 2004. [orig.] ГОРТАН ПРЕМК, Даринка. Полисемија и организација лексичког система у српском језику, Завод за уџбенике и наставна средства, Београд, 2004.

GORTAN PREMK 2014: GORTAN PREMK, Darinka. „Definisanje u srpskoj leksikografiji”, Savremena srpska leksikografija u teoriji i praksi, Beograd: Filološki fakultet, 2014, 131-139. [orig.] ГОРТАН ПРЕМК, Даринка. „Дефинисање у српској лексикографији”, Савремена српска лексикографија у теорији и пракси, Београд: Филолошки факултет, 2014, 131-139.

MATIJAŠEVIĆ 2019: MATIJAŠEVIĆ, Jelka. Derivatološko-leksikološka istraživanja ruskog i srpskog jezika. Novi Sad: Filozofski fakultet, 2019. [orig.] МАТИЈАШЕВИЋ, Јелка. Дериватолошко-лексиколошка истраживаюа руског и српског језика. Нови Сад: Филозофски факултет, 2019.

MAROJEVIĆ 2005: MAROJEVIĆ, Radmilo. „Tvorba reči u savremenom srpskom jeziku Ivana Klajna (1)”, Srpski jezik 10/1-2, 2005, 685-780. [orig.] МАРОЈЕВИЋ, Радмило. „Творба речи у савременом српском језику Ивана Клајна (1)", Српски језик 10/1-2, 2005, 685-780.

MASLOVA 2004: MASLOVA, Valentina Avraamovna. Lingvokul'turologiia, Moskva: Akademiia, 2004. [orig.] МАСЛОВА, Валентина Авраамовна. Лингвокультурология, Москва: Академия, 2004.

RANĐELOVIĆ 2012: RANĐELOVIĆ, Ana. „Metaforična značenja zoonima koji se odnose na ljudske osobine”, Naš jezik, XLIII/3-4, Beograd: Institut za srpski jezik SANU, 2012, 89-107. [orig.] РАНЂЕЛОВИЋ, Ана. „Метафорична значења зоонима који се односе на људске особине”, Наш језик, XLIII/3-4, Београд: Институт за српски језик САНУ, 2012, 89-107.

RISTIĆ 2004: RISTIĆ, Stana. Ekspresivna leksika u srpskom jeziku, Institut za srpski 
jezik, Beograd, 2004. [orig.] РИСТИЋ, Стана. Експресивна лексика у српском језику, Институт за српски језик, Београд, 2004.

RISTIVOJEVIĆ RAJKOVIĆ 2008: RISTIVOJEVIĆ RAJKOVIĆ, Nataša. „Zoonimska metaforika o muškarcima i ženama”, Philologia, br. 6, Beograd: Filološki fakultet, 2008, 45-52. [orig.] РИСТИВОЈЕВИЋ РАЈКОВИЋ, Наташа. „Зоонимска метафорика о мушкарцима и женама”, Philologia, бр. 6, Београд: Филолошки факултет, 2008, 45-52.

ROZENTALJ, GOLUB i dr 2010: ROZENTAL', D.E, GOLUB, I.B, Telenkova, M.A, Sovremennyi russkii iazyk, Moskva: Airis-press, 2010. [orig.] РОЗЕНТАЛЬ, Д.Э, ГОЛУБ, И.Б, Теленкова, М.А, Современный русский язык, Москва: Айрис-пресс, 2010.

ŠTASNI 2013: ŠTASNI, Gordana. Reči o čoveku (Nominacija čoveka u srpskom jeziku), Novi Sad: Filozofski fakultet, 2013. [org.] ШТАСНИ, Гордана. Речи о човеку (Номинација човека у српском језику), Нови Сад: Филозофски факултет, 2013.

\section{Извори}

BTSK: Kuznetsov, Sergei Aleksandrovich (gl. red.). Bol'shoj tolkovyj slovar' russkogo jazyka. <https://gufo.me/dict/kuznetsov>. 25.02.2021.[orig.] Кузнецов, Сергей Александрович (гл. ред.). Большой толковый словарь русского языка. <https://gufo.me/dict/kuznetsov> 25.02.2021.

TSRS: Elistratov, Vladimir Stanislavovich (gl. red.). Tolkovyj slovar' russkogo slenga. Moskva: AST-PRESS, 2010. [orig.] Елистратов, Владимир Станиславович (гл. ред.). Толковый словарь русского сленга. Москва: АСТ-ПРЕСС, 2010.

RMS: Rečnik srpskohrvatskoga književnog jezika, Novi Sad: Matica srpska, 1967-1976. [orig.] Речник српскохрватскога книжевног језика, Нови Сад: Матица српска, 1967-1976.

RSANU: Rečnik srpskohrvatskoga književnog i narodnog jezika, I-XVIII, Beograd: Institut za srpski jezik i književnost, 1959-. [orig.] Речник српскохрватскога књижевног и народног језика, I-XVIII, Београд: Институт за српски језик и књижевност, 1959-.

RSJ 2007: Rečnik srpskoga jezika, Novi Sad: Matica srpska, 2007. [orig.] Речник српскога језика, Нови Сад: Матица српска, 2007.

RSŽ: Dragoslav Andrić, Dvosmerni rečnik srpskog žargona, Bookwork, 2005. [orig.] Драгослав Андрић, Двосмерни речник српскогжаргона, Bookwork, 2005.

SE: Efremova, Tat'iana Fedorovna. Novyj slovar' russkogo jazyka, <https://www. efremova.info>. 19.02.2021. [orig.] Ефремова, Татьяна Федоровна. Новый словарь русского языка, <https://www.efremova.info> 19.02.2021. 
Елена Лепоевич

\section{ЗООНИМЫ В ФУНКЦИИ ИНВЕКТИВЫ: РАЗВЕ ЧЕЛОВЕК ДЛЯ ЧЕЛОВЕКА ВСЕГО ЛИШЬ ВОЛК?}

Вторичные семантические реализации существительных, основная функция которых называть животных, могут относиться как к предметам, так и к людям. Продуктивность вторичных значений, относящихся к человеку очень высока, особенно когда они указывают на отрицательные характеристики.

В статье представлена попытка анализа и классификации вторичных инвективных значений зоонимов, выявленных в словарях русского и сербского языков, а также сравнение между двумя языками как вторичных значений так и самых зоонимов, у которых эти значения развились. Помимо лексико-семантических признаков, опираясь на принципы сравнительного анализа, в данной статье мы обсудим и словообразовательный аспект, рассмотрим особенности развития многозначности.

В ходе исследования применялись традиционные лингвистические методы: метод сплошной выборки, лексико-семантический, сопоставительный, описательный метод, количественный анализ и анализ словарных дефиниций, применение которого способствовало определению элементарных значимых частиц семантической структуры зоонимов.

Ключевые слова: зооним, инвектива, семантическая деривация, многозначность, вторичное значение, русский язык, сербский язык 